\title{
Histopathological Examination of Post-Tonsillectomy Specimens at a Southern Tertiary Hospital of Nigeria from Jan.2005- Dec.2012
}

\author{
Martin Anazodo Nnoli ${ }^{1}$, Collins Ogbonna Nwabuko ${ }^{2}$, Chinenye Nnoli ${ }^{3}$ \\ ${ }^{1}$ University of Calabar Teaching Hospital,Dept of Pathology, Calabar. \\ ${ }^{2}$ Federal Medical Centre,Dept of Haematology,Umuahia. \\ ${ }^{3}$ University of UyoTeaching Hospital, Dept of Pediatrics,Uyo.
}

\begin{abstract}
Aims \& Objectives: Is to determine the necessity of histological examinations of post-tonsillectomy specimens.

Materials and Methods:A study of post-tonsillectomy histologically diagnosed were analyzed from January 2005 to December,2012. Almost all samples seen within this period showed reactive lymphoid hyperplasia. A total of 392 samples were collected,of which 228 were males and 164 females. The analyses was done using SPSS version 16. This was represented according to age range and gender distribution per each year of study. They were also further displayed in both bar and pie chat.

Results: The percentage of female affected within the study was 164(41.84\%) and that of males was $228(58.16 \%)$. The study also showed the most affected age range are children under 10 years and this is closely followed by age range of 10-20years. These goes to show that the pediatric age is the most vulnerable age that was mostly affected.

Conclusions: These shows that lower age ranges are more affected and the males are the most vulnerable in our study. We could not deduce what actually may be the factor contributing to the increase in lesion of this gender.
\end{abstract}

Keywords: Post-tonsillectomy Samples, Histology, Examination

\section{Introduction:}

The lymphoid tissue of the body plays an important role in the recognition and processing of foreign antigens such as viruses,fungi and bacteria. In addition,the lymphoid tissue has a protective function through a variety of direct and indirect mechanism. In responding to antigenic challenges,lymphoid cells proliferate,thus increasing their numbers, to combat the offending agent more effectively. This proliferation results in enlargement of the lymphoid tissue which is clinically termed lymphoid hyperplasia. These could affect lymph nodes, the lymphoid tissue of waldeyers ring or the aggregates of lymphoid tissue that are normally scattered throughout the oral cavity especially in the orophyarnx,soft palate,lateral tongue and the floor of the mouth.

Tonsilar size is variable from one person to another, but lymphoid tissue is normally more prominent in the younger individuals, usually reaching the peak early during the second decade of life and gradually diminishing thereafter. A few of patients have such large tonsils that it seems as if they would occlude airways so called 'kissing tonsils'.

Harshmohan study also noted that lymph nodes undergo reactive changes in response to a wide variety of stimuli which include microbial infections, drugs, environmental pollutants, tissue injury, immune complexes and malignant neoplasm. The most common causes of lymph node enlargement are inflammatory and immune reactions aside from primary malignant neoplasm and metastatic tumor deposits. Those due to primary inflammatory reactions are termed reactive lymphadenitis. Those due to primary immune reactions are referred to as lymphadenopathy. ${ }^{2}$

Lingual tonsils hyperplasia though rare but may cause obstructive sleep apnea (OSA). This is why it is adviceable to evaluate this area during physical examination of patients with apnoea. ${ }^{3}$

Tonsillectomy which is removal of palatine tonsils has been a long practiced procedure hence is performed for a wide range of indications. This is divided into therapeutics,diagnostics and access for other procedures. However, the most common indication has been in infective causes. The other indications are patients with obstructive symptoms such as snoring and sleep apnea. Regardless of the indications, tonsillectomy specimens are routinely sent for histological analysis because of the fear that tonsils may harbor malignancy. ${ }^{4}$

The routine examination of this specimen(tonsils) have been intensified in most developing countries as a routine in physical examination. There is now divided opinion as to why this should be encouraged. ${ }^{5}$ 
However, it is adviceable to perform a diagnostic tonsillectomy to exclude malignancy once there is tonsilar asymmetry. It is worthy to note that tonsilar enlargement may be a reactive response to a nearby primary tumor hence the need to rule out any local-regional primary lymphoma. ${ }^{6}$

It is not out of place that benign reactive hyperplasia of local-regional lymph nodes in response to malignancy has been seen as is not uncommon event in head and neck malignant lesions. These has equally been seen in response to squamous cell carcinoma affectation of the head and neck region. ${ }^{7,8,9}$ In our view, it showed that tonsils could become hyperplastic as a response to several microbial infections.

It is imperative that exact pathophysiology for the cause of benign reactive hyperplasia in response to tumor is unknown; as the widely accepted theory of immunological reaction to tumor antigens is well known. ${ }^{8,10,11}$ This is due to the fact that lymphocytes and macrophages of hyperplastic node are specifically cytotoxic to autologous tumour cells. ${ }^{10,11}$ However,the specific tumor antigens for the lymphoma are not yet known. ${ }^{12,13,14,15,16}$ The lack of response of benign tonsilar reactive hyperplasia to local lymphoma, unlike to lymph nodes and that of waldeyer's ring is likely due to unavailability of afferent lymphatic channels. ${ }^{17}$ Our study shows the high incidence of occurrence at lower age ranges and male though more affected as we could not deduce what actual might be the cause in this particular gender. However, we are of the opinion since this is of pediatric age there are possibility that there is late in development of adaptive immunity and lack of previous infections as to develop adequate antibodies to consequent exposure to microbes.

MATERIALS AND METHOD: A cross sectional study of post -tonsillectomy of 392 specimen study from 2005-2012 was undertaken. 228(58.16\%) of the study were males and the rest 164(41.84\%) were females. These was analyzed using SPSS version 16; and all ages/sexes(gender) were evaluated.They result obtained were presented in different modules/chats.

\section{Results:}

GENERAL DISTRIBUTION OF POST-TONSILLECTOMY SPECIMENS FROM 2005 - 2012 2005

\begin{tabular}{|ll|l|l|l|l|}
\hline & & & & & Cumulative \\
& & Frequency & Percent & Valid Percent & Percent \\
\hline Valid & Under 10 years & 9 & 8.6 & 60.0 & 60.0 \\
& 10 - 20 years & 3 & 2.9 & 20.0 & 80.0 \\
& 20 - 30 years & 3 & 2.9 & 20.0 & 100.0 \\
& Total & 15 & 14.3 & 100.0 & \\
Missing & System & 90 & 85.7 & & \\
Total & 105 & 100.0 & & \\
\hline
\end{tabular}

\section{Histopathological Exam of Post-Tonsillectomy Specimens in 2005}

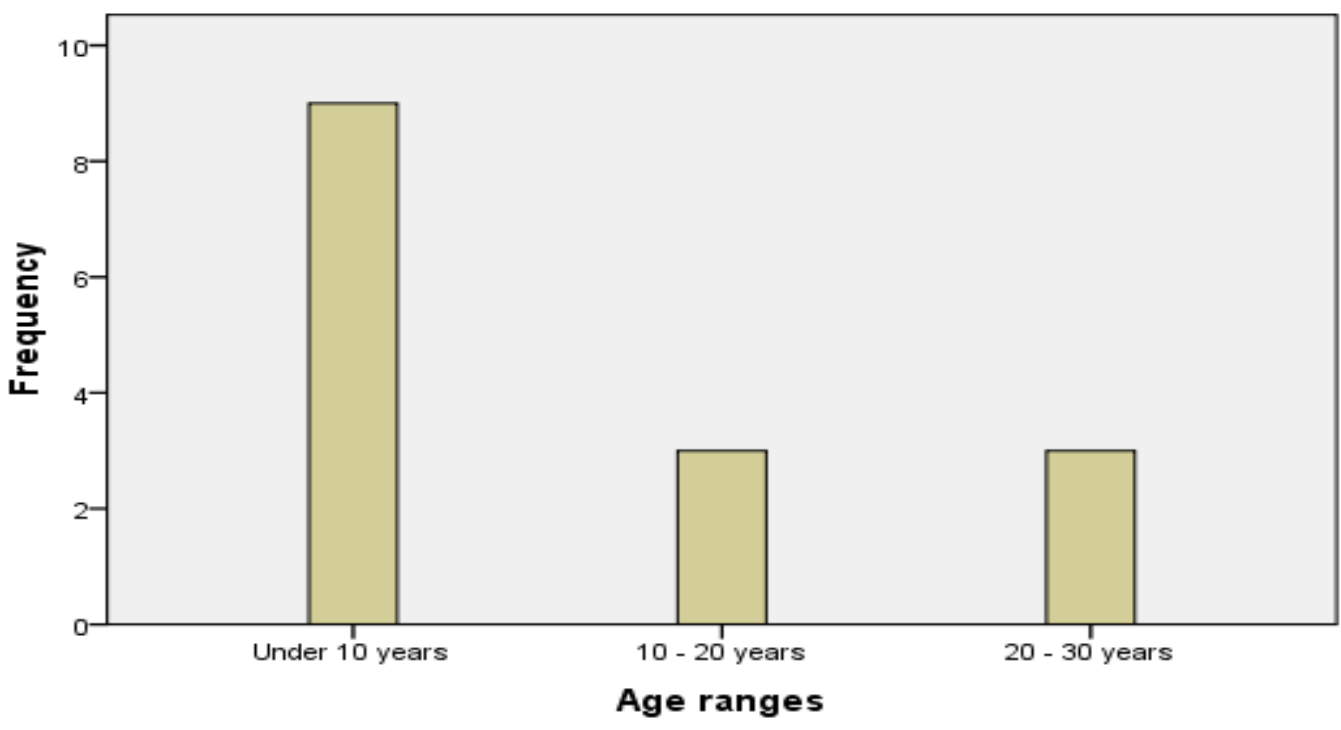


Histo pathological Exam of Post-Tonsillectomy Specimens in 2005

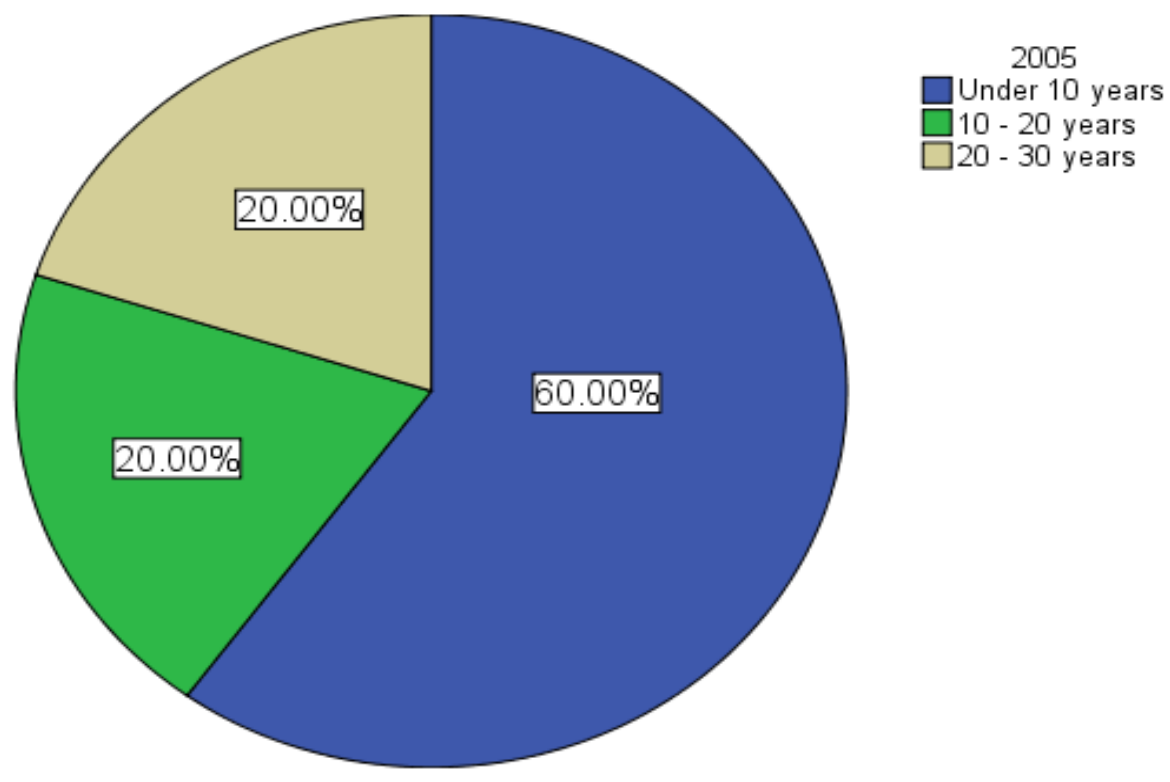

2006

\begin{tabular}{|ll|l|l|l|l|}
\hline & & & & & Cumulative \\
& & Frequency & Percent & Valid Percent & Percent \\
\hline Valid & Under 10 years & 15 & 14.3 & 88.2 & 88.2 \\
& 10 - 20 years & 2 & 1.9 & 11.8 & 100.0 \\
& Total & 17 & 16.2 & 100.0 & \\
Missing & System & 88 & 83.8 & & \\
Total & & 105 & 100.0 & & \\
\hline
\end{tabular}

\section{Histopathological Exam of Post-Tonsillectomy Specimens in 2006}

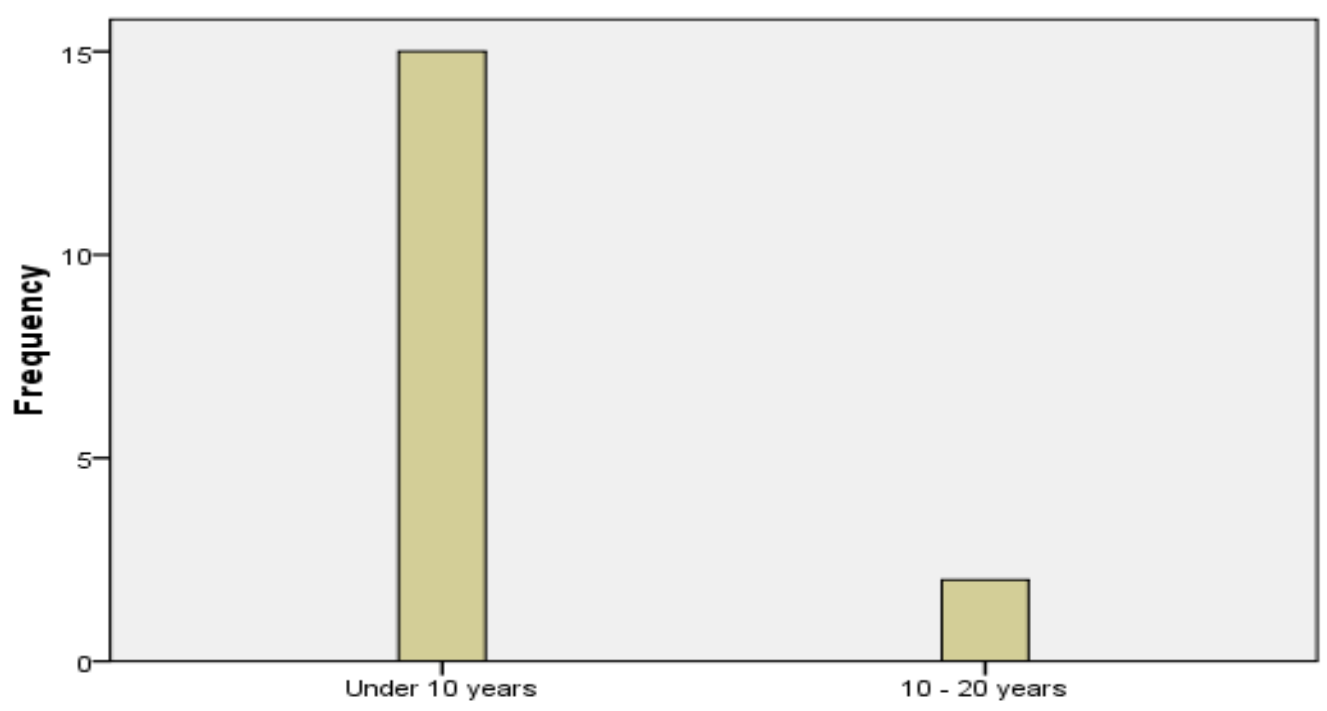

Age ranges 
Histopathological Exam of Post-Tonsillectomy Specimens in 2006

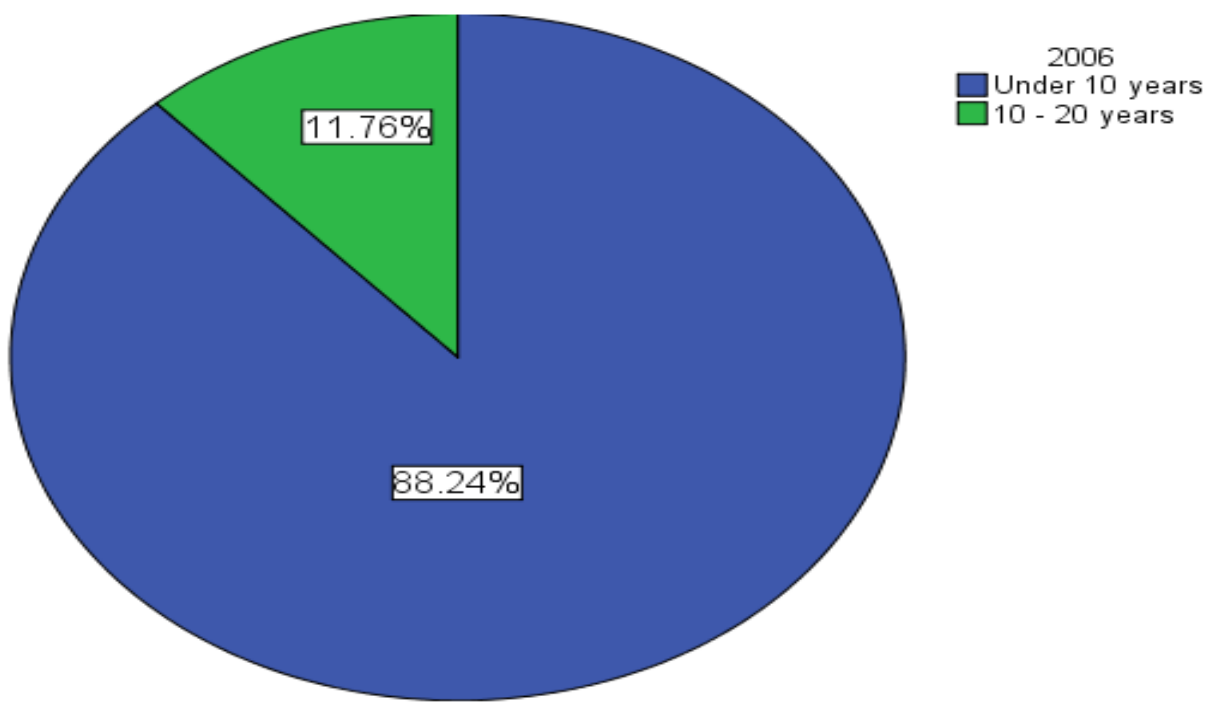

2007

\begin{tabular}{|c|c|c|c|c|c|}
\hline & & Frequency & Percent & Valid Percent & $\begin{array}{l}\text { Cumulative } \\
\text { Percent }\end{array}$ \\
\hline \multirow[t]{4}{*}{ Valid } & Under 10 years & 27 & 25.7 & 87.1 & 87.1 \\
\hline & 20 - 30 years & 3 & 2.9 & 9.7 & 96.8 \\
\hline & $30-40$ years & 1 & 1.0 & 3.2 & 100.0 \\
\hline & Total & 31 & 29.5 & 100.0 & \\
\hline Missing & System & 74 & 70.5 & & \\
\hline Total & & 105 & 100.0 & & \\
\hline
\end{tabular}

Histopathological Exam of Post-Tonsillectomy Specimens in 2007

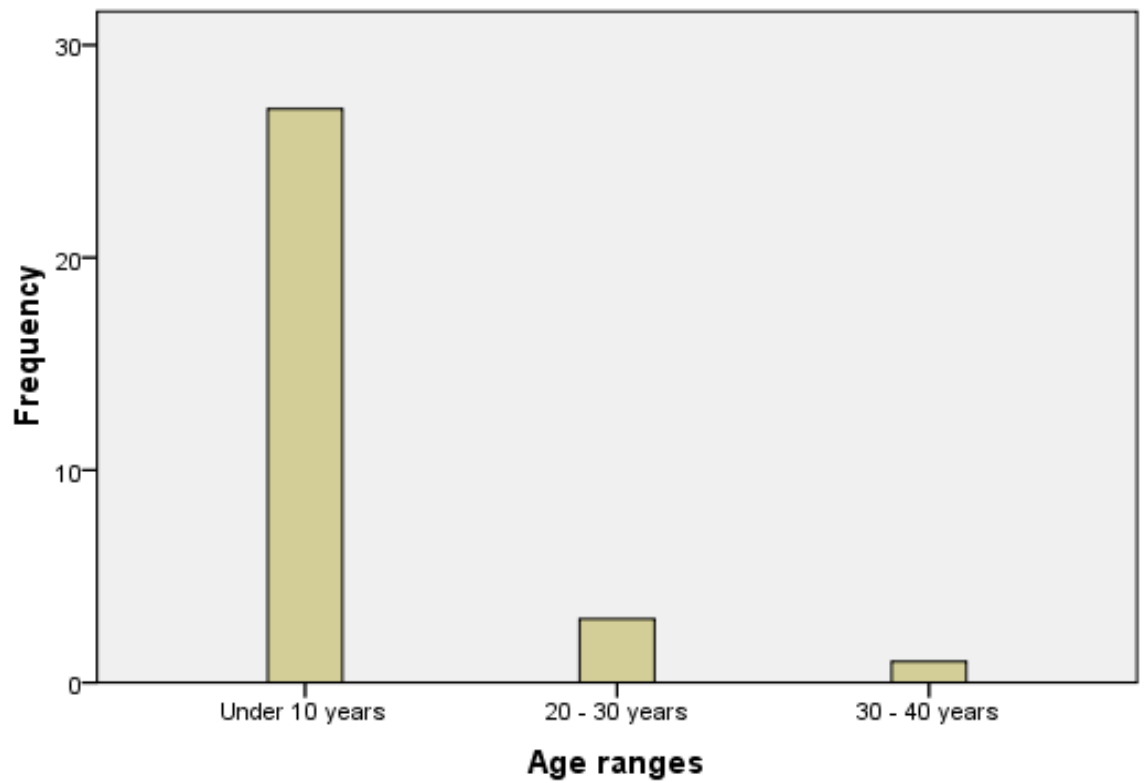


Histopathological Exam of Post-Tonsillectomy Specimens in 2007

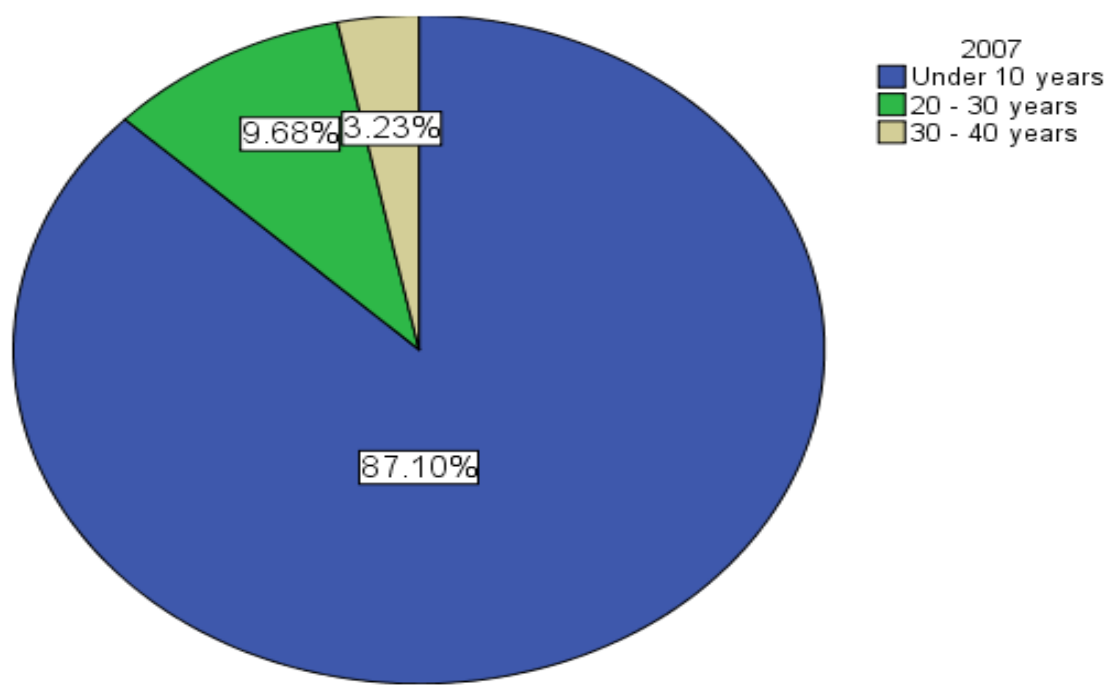

2008

\begin{tabular}{|ll|l|l|l|l|}
\hline & & Frequency & Percent & Valid Percent & $\begin{array}{l}\text { Cumulative } \\
\text { Percent }\end{array}$ \\
\hline Valid & Under 10 years & 38 & 36.2 & 79.2 & 79.2 \\
& 10 - 20 years & 1 & 1.0 & 2.1 & 81.2 \\
& 20 - 30 years & 2 & 1.9 & 4.2 & 85.4 \\
& 30 - 40 years & 4 & 3.8 & 8.3 & 93.8 \\
& 40 - 50 years & 1 & 1.0 & 2.1 & 95.8 \\
& Above 50 years & 2 & 1.9 & 4.2 & 100.0 \\
Missing & System & 48 & 45.7 & 100.0 & \\
Total & Total & 105 & 54.3 & & \\
\hline
\end{tabular}

Histopathological Exam of Post-Tonsillectomy Specimens in 2008

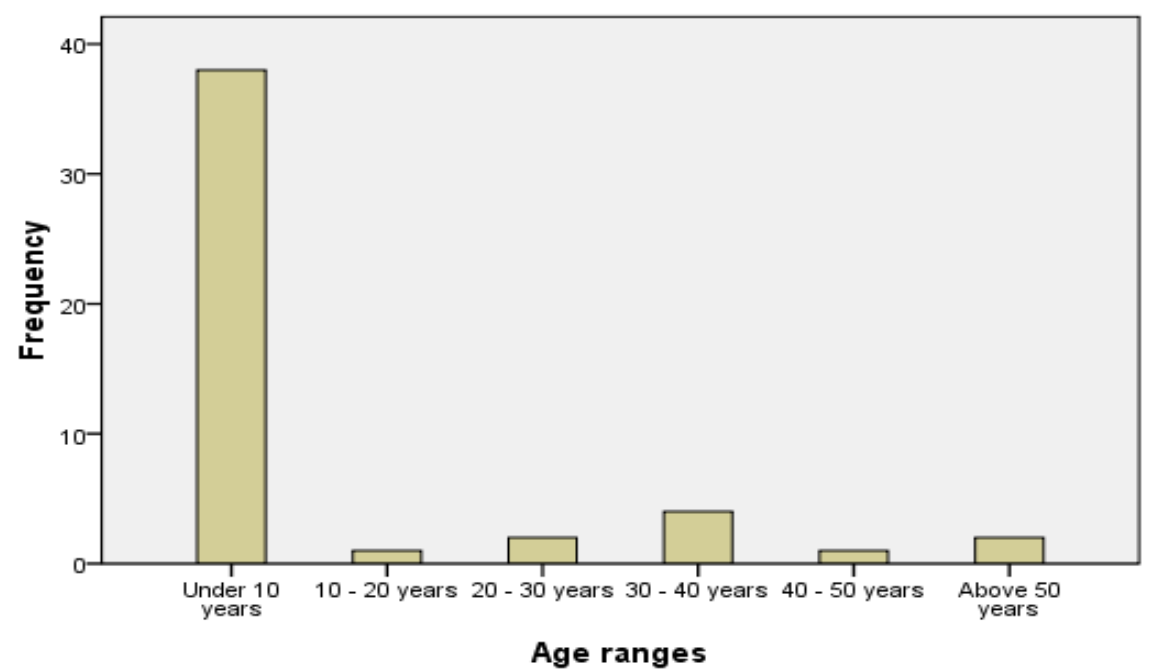


Histopathological Exam of Post-Tonsillectomy Specimens in 2008

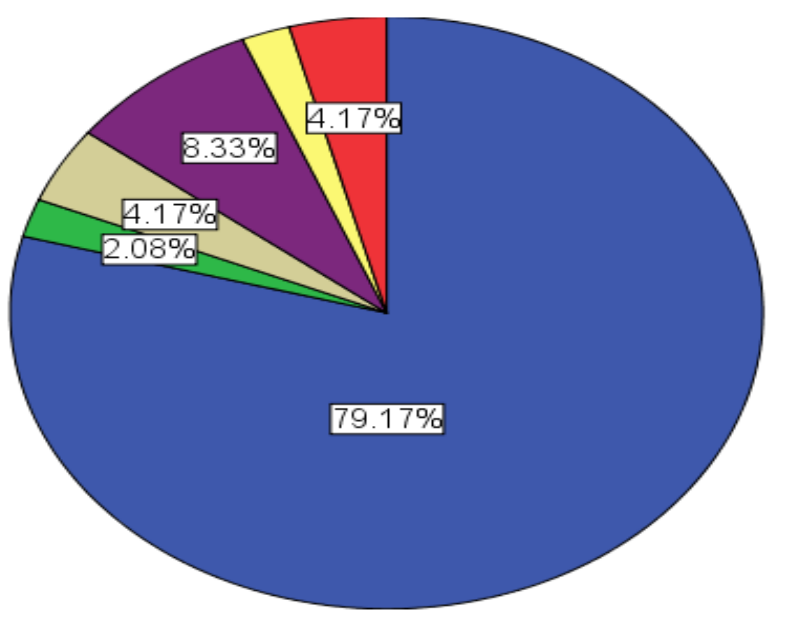

$$
2008
$$

$\square$ Under 10 years

$\square 10$ - 20 years

20 - 30 years

30 - 40 years

40 - 50 years

Above 50 years

2009

\begin{tabular}{|ll|l|l|l|l|}
\hline & & Frequency & Percent & Valid Percent & $\begin{array}{l}\text { Cumulative } \\
\text { Percent }\end{array}$ \\
\hline Valid & Under 10 years & 26 & 24.8 & 68.4 & 68.4 \\
& 10 - 20 years & 6 & 5.7 & 15.8 & 84.2 \\
& 20 - 30 years & 1 & 1.0 & 2.6 & 86.8 \\
& 30 - 40 years & 4 & 3.8 & 10.5 & 97.4 \\
& 40 - 50 years & 1 & 1.0 & 2.6 & 100.0 \\
& Total & 38 & 36.2 & 100.0 & \\
Missing & System & 67 & 63.8 & & \\
Total & & 105 & 100.0 & & \\
\hline
\end{tabular}

Histopathological Exam of Post-Tonsillectomy Specimens in 2009

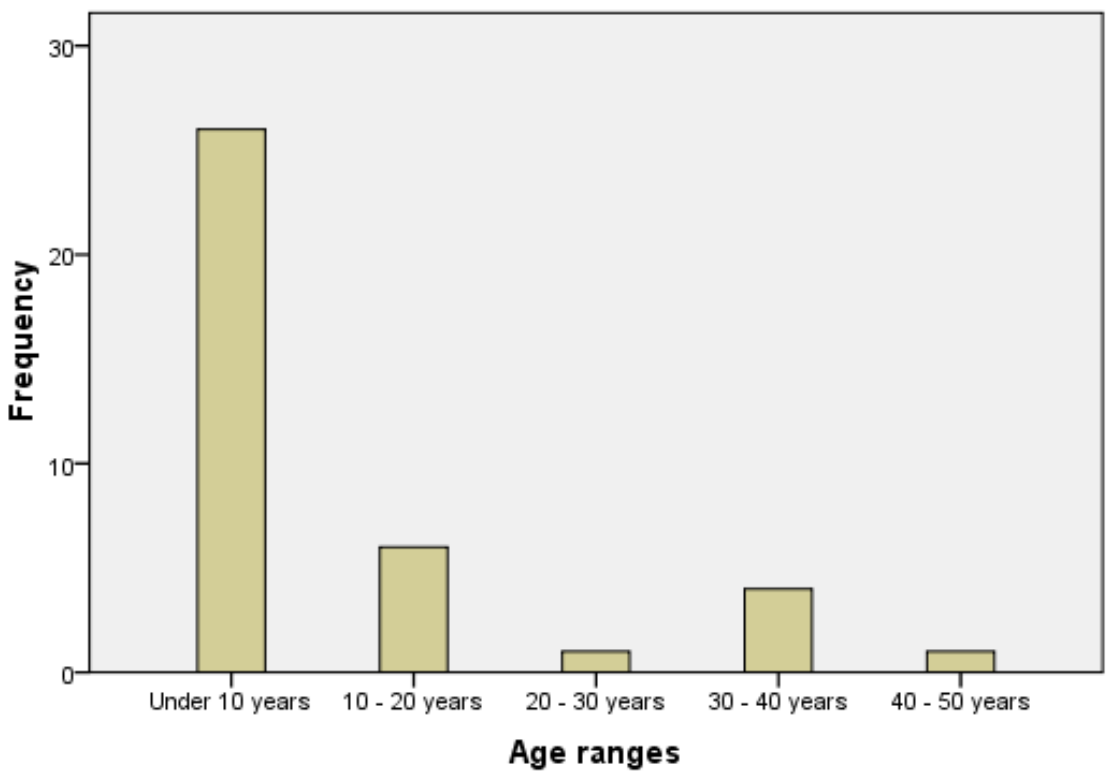


Histopathological Exam of Post-Tonsillectomy Specimens in 2009

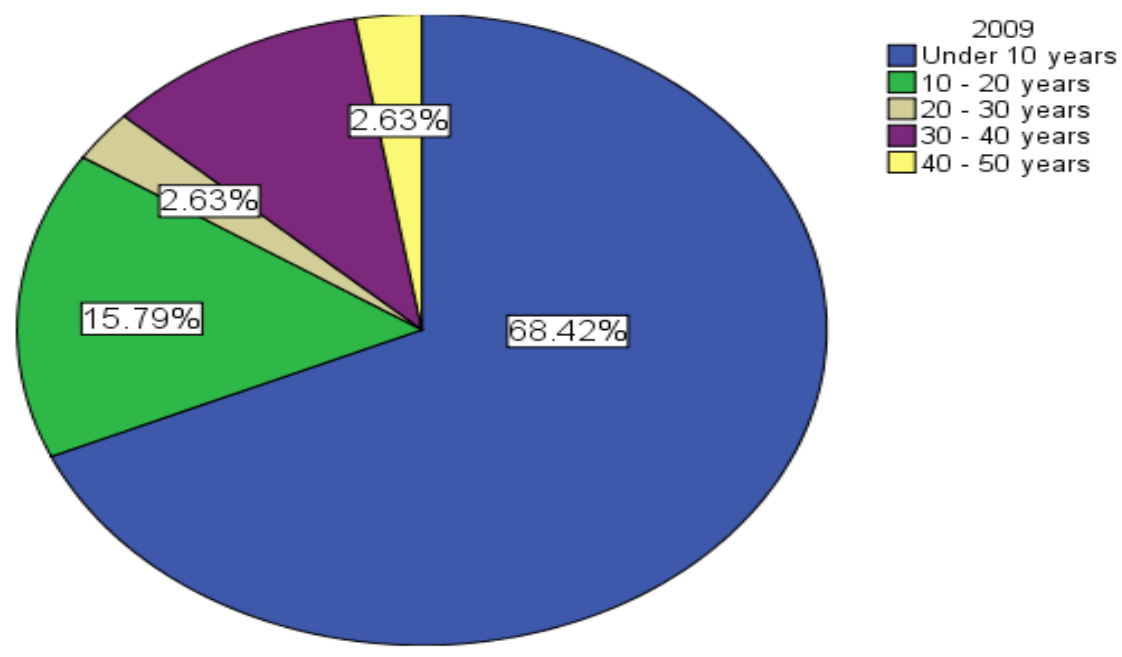

2010

\begin{tabular}{|ll|l|l|l|l|}
\hline & & Frequency & Percent & Valid Percent & $\begin{array}{l}\text { Cumulative } \\
\text { Percent }\end{array}$ \\
\hline Valid & Under 10 years & 41 & 39.0 & 75.9 & 75.9 \\
& 10 - 20 years & 4 & 3.8 & 7.4 & 83.3 \\
& 20 - 30 years & 2 & 1.9 & 3.7 & 87.0 \\
& $30-40$ years & 1 & 1.0 & 1.9 & 88.9 \\
& 40 - 50 years & 4 & 3.8 & 7.4 & 96.3 \\
& Above 50 years & 2 & 1.9 & 3.7 & 100.0 \\
Missing & Total & 54 & 51.4 & 100.0 & \\
Total & System & 51 & 48.6 & & \\
\hline
\end{tabular}

\section{Histopathological Exam of Post-Tonsillectomy Specimens in 2010}

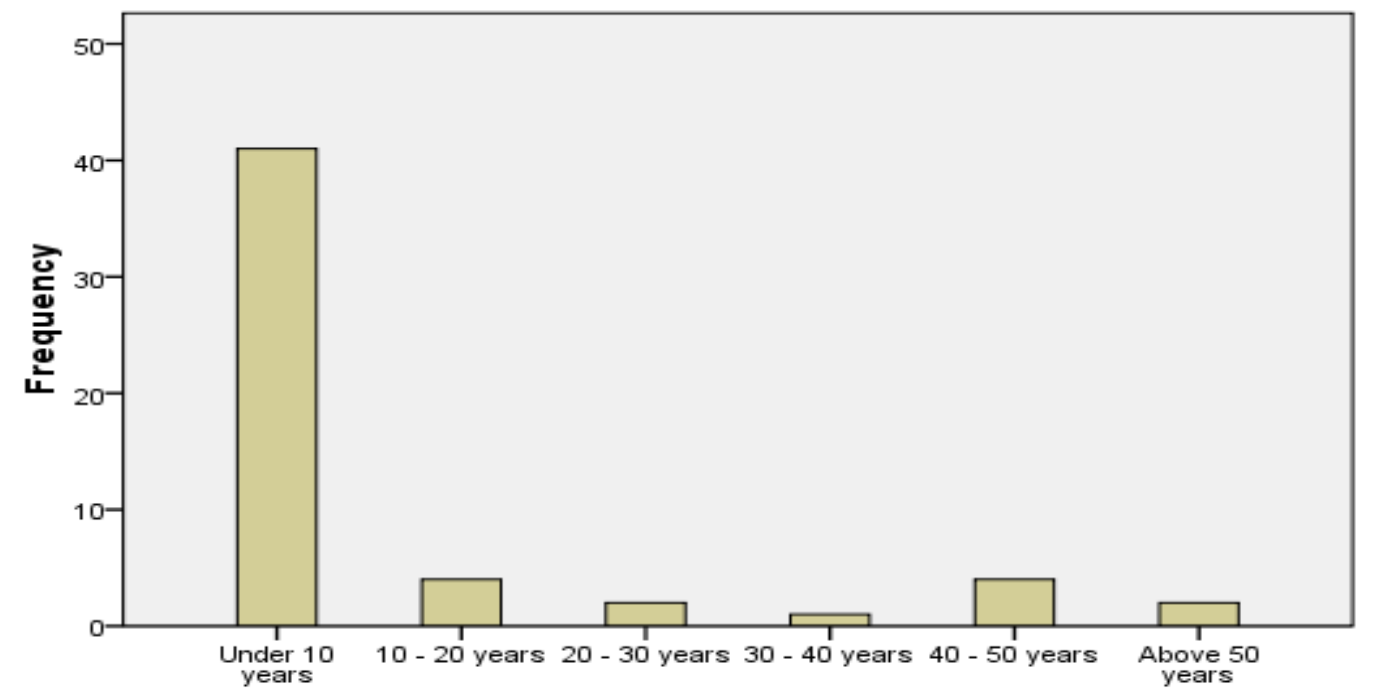

Age ranges 
Histopathological Exam of Post-Tonsillectomy Specimens in 2010

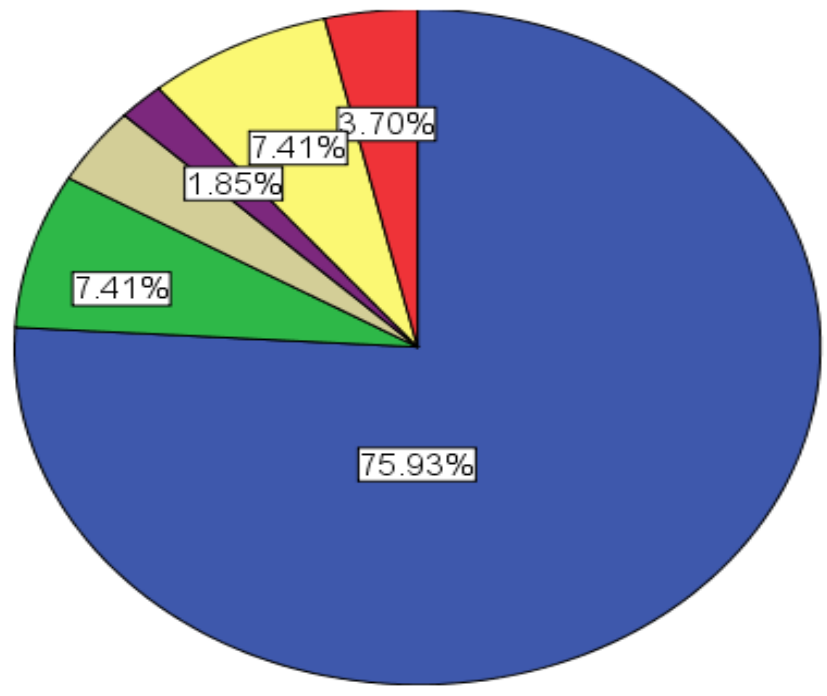

2010

$\square$ Under 10 years

10 - 20 years

20 - 30 years

30 - 40 years

40 - 50 years

Above 50 years

2011

\begin{tabular}{|ll|l|l|l|l|}
\hline & & & & & Cumulative \\
\hline Valid & Under 10 years & 70 & Percent & Valid Percent & $\begin{array}{l}\text { Percent } \\
\end{array}$ \\
& 10 - 20 years & 6 & 66.7 & 84.3 & 84.3 \\
& 20 - 30 years & 6 & 5.7 & 7.2 & 91.6 \\
& 30 - 40 years & 1 & 5.7 & 7.2 & 98.8 \\
& Total & 83 & 1.0 & 1.2 & 100.0 \\
Missing & System & 22 & 79.0 & 100.0 & \\
Total & & 105 & 21.0 & & \\
\hline
\end{tabular}

Histopathological Exam of Post-Tonsillectomy Specimens in 2011

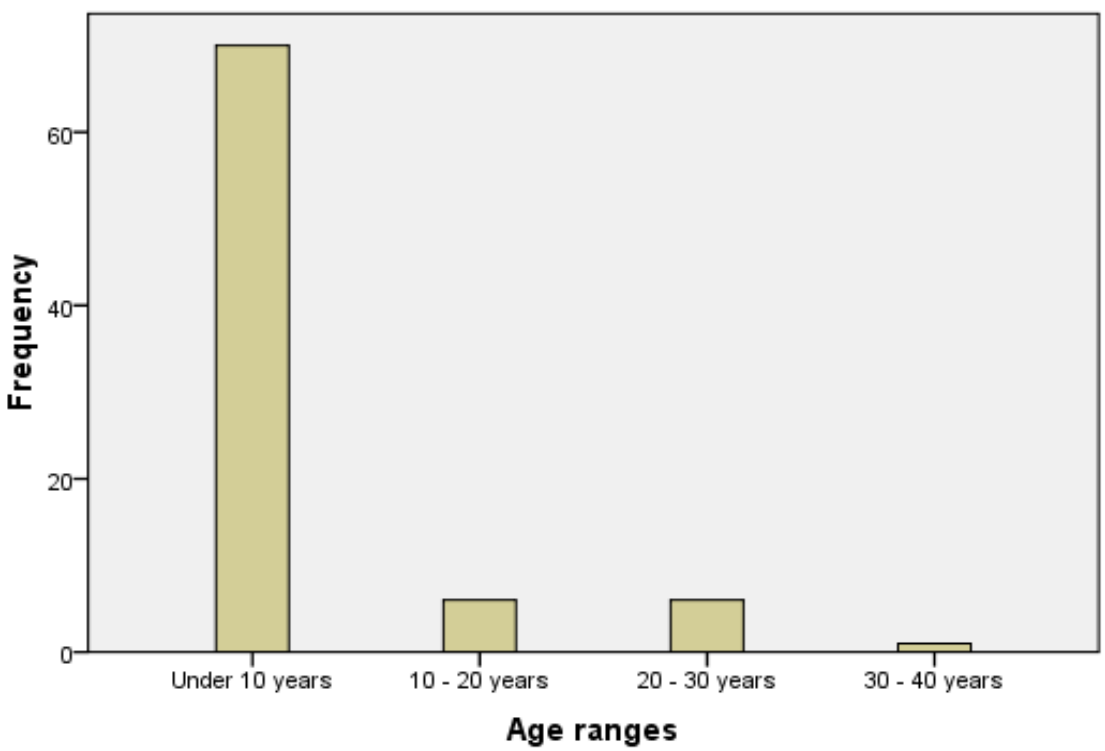


Histopathological Exam of Post-Tonsillectomy Specimens in 2011

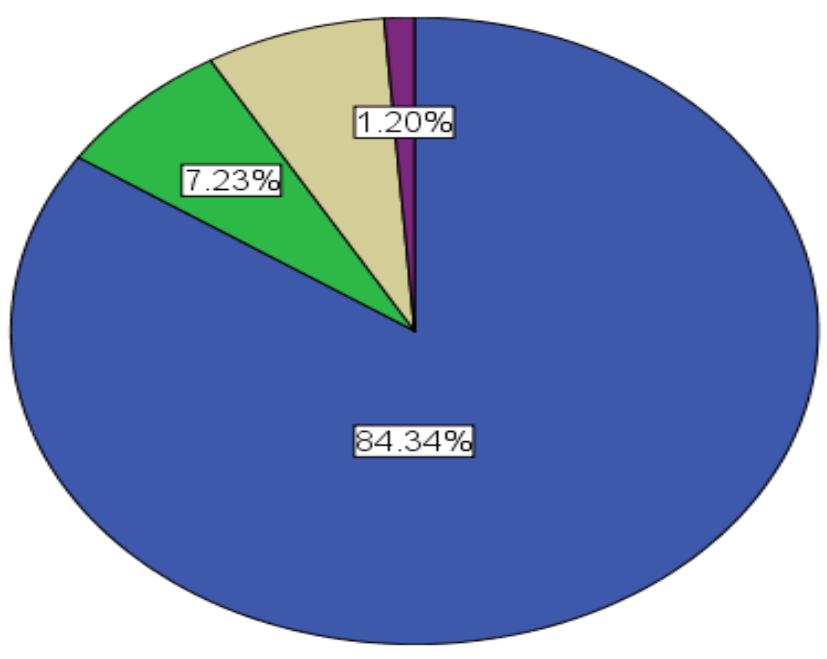

2011

Under 10 years

10 - 20 years

20 - 30 years

30 - 40 years

2012

\begin{tabular}{|c|c|c|c|c|c|}
\hline & & Frequency & Percent & Valid Percent & $\begin{array}{l}\text { Cumulative } \\
\text { Percent }\end{array}$ \\
\hline \multirow[t]{7}{*}{ Valid } & Under 10 years & 89 & 84.8 & 84.8 & 84.8 \\
\hline & 10 - 20 years & 5 & 4.8 & 4.8 & 89.5 \\
\hline & 20 - 30 years & 7 & 6.7 & 6.7 & 96.2 \\
\hline & $30-40$ years & 1 & 1.0 & 1.0 & 97.1 \\
\hline & 40 - 50 years & 2 & 1.9 & 1.9 & 99.0 \\
\hline & Above 50 years & 1 & 1.0 & 1.0 & 100.0 \\
\hline & Total & 105 & 100.0 & 100.0 & \\
\hline
\end{tabular}

\section{Histopathological Exam of Post-Tonsillectomy Specimens in 2012}

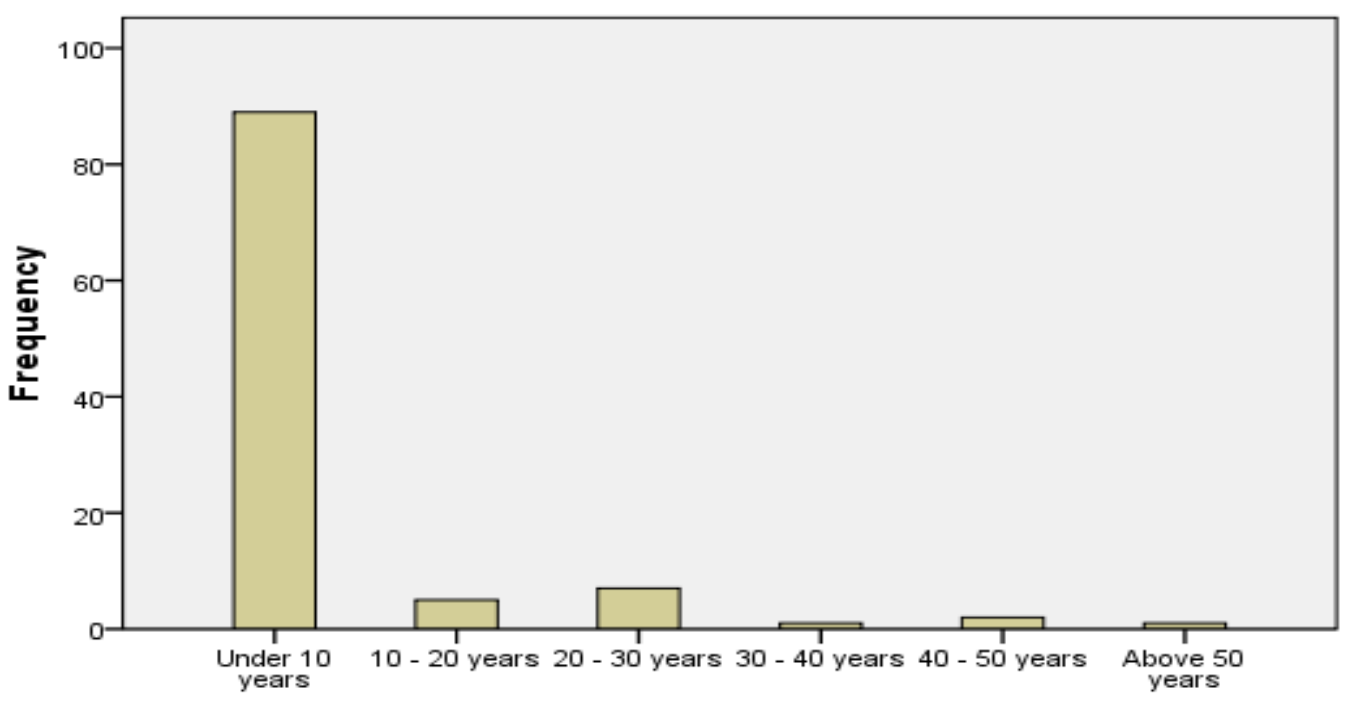

Age ranges 
Histopathological Exam of Post-Tonsillectomy Specimens in 2012

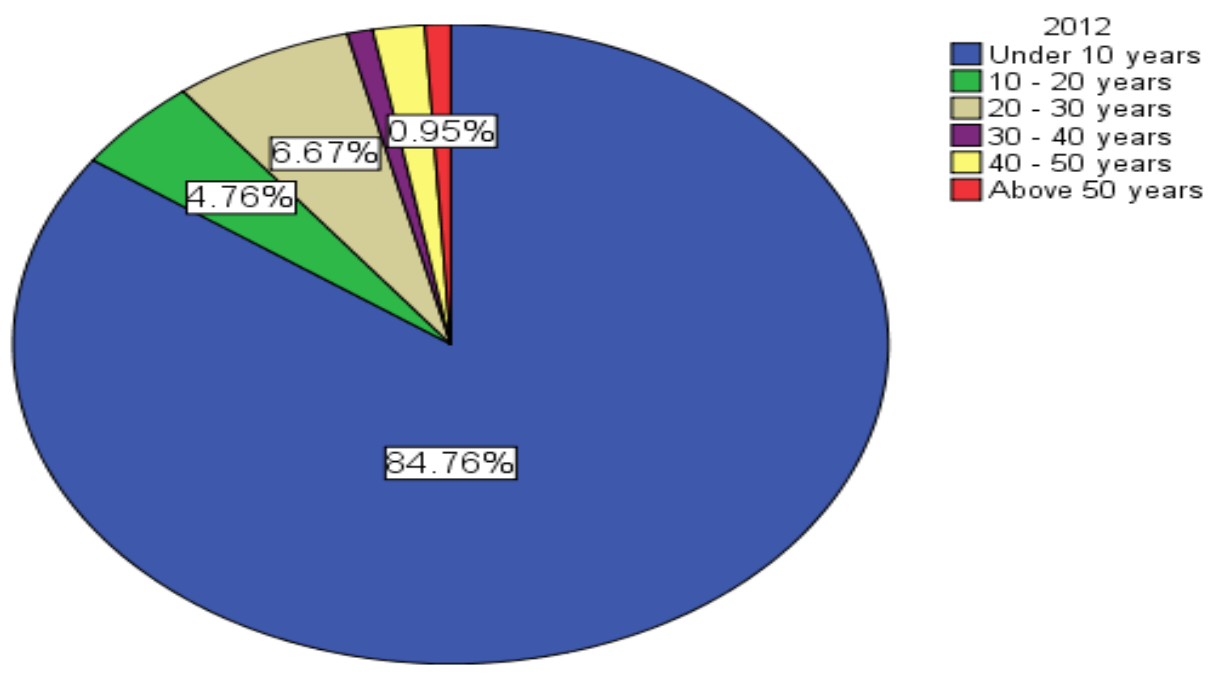

2005 - Gender

\begin{tabular}{|ll|l|l|l|l|}
\hline & & Frequency & Percent & Valid Percent & $\begin{array}{l}\text { Cumulative } \\
\text { Percent }\end{array}$ \\
\hline Valid & Male & 11 & 64.7 & 68.8 & 68.8 \\
& Female & 5 & 29.4 & 31.2 & 100.0 \\
& Total & 16 & 94.1 & 100.0 & \\
Missing & System & 1 & 5.9 & & \\
Total & & 17 & 100.0 & & \\
\hline
\end{tabular}

2006 - Gender

\begin{tabular}{|c|c|c|c|c|c|}
\hline & & Frequency & Percent & Valid Percent & $\begin{array}{l}\text { Cumulative } \\
\text { Percent }\end{array}$ \\
\hline \multirow[t]{3}{*}{ Valid } & Male & 9 & 52.9 & 52.9 & 52.9 \\
\hline & Female & 8 & 47.1 & 47.1 & 100.0 \\
\hline & Total & 17 & 100.0 & 100.0 & \\
\hline
\end{tabular}

2007 - Gender

\begin{tabular}{|ll|l|l|l|l|}
\hline & & Frequency & Percent & Valid Percent & $\begin{array}{l}\text { Cumulative } \\
\text { Percent }\end{array}$ \\
\hline Valid & Male & 16 & 51.6 & 51.6 & 51.6 \\
& Female & 15 & 48.4 & 48.4 & 100.0 \\
& Total & 31 & 100.0 & 100.0 & \\
\hline
\end{tabular}

2008 - Gender

\begin{tabular}{|ll|l|l|l|l|}
\hline & & Frequency & Percent & Valid Percent & $\begin{array}{l}\text { Cumulative } \\
\text { Percent }\end{array}$ \\
\hline Valid & Male & 29 & 60.4 & 60.4 & 60.4 \\
& Female & 19 & 39.6 & 39.6 & 100.0 \\
& Total & 48 & 100.0 & 100.0 & \\
\hline
\end{tabular}


2009 - Gender

\begin{tabular}{|ll|l|l|l|l|}
\hline & & Frequency & Percent & Valid Percent & $\begin{array}{l}\text { Cumulative } \\
\text { Percent }\end{array}$ \\
\hline Valid & Male & 17 & 44.7 & 44.7 & 44.7 \\
& Female & 21 & 55.3 & 55.3 & 100.0 \\
& Total & 38 & 100.0 & 100.0 & \\
\hline
\end{tabular}

2010 - Gender

\begin{tabular}{|ll|l|l|l|l|}
\hline & & & & Cumulative \\
& & Frequency & Percent & Valid Percent & $\begin{array}{l}\text { Percent } \\
\text { Valid }\end{array}$ \\
& Male & 29 & 53.7 & 53.7 & 53.7 \\
& Female & 25 & 46.3 & 46.3 & 100.0 \\
& Total & 54 & 100.0 & 100.0 & \\
\hline
\end{tabular}

2011 - Gender

\begin{tabular}{|ll|l|l|l|l|}
\hline & & & & Cumulative \\
& & Frequency & Percent & Valid Percent & $\begin{array}{l}\text { Percent } \\
\text { Palid }\end{array}$ \\
& Male & 56 & 67.5 & 67.5 & 67.5 \\
& Female & 27 & 32.5 & 32.5 & 100.0 \\
& Total & 83 & 100.0 & 100.0 & \\
\hline
\end{tabular}

2012 - Gender

\begin{tabular}{|ll|l|l|l|l|}
\hline & & & & \\
& & Frequency & Percent & Valid Percent & $\begin{array}{l}\text { Cumulative } \\
\text { Percent }\end{array}$ \\
\hline Valid & Male & 61 & 58.1 & 58.1 & 58.1 \\
& Female & 44 & 41.9 & 41.9 & 100.0 \\
& Total & 105 & 100.0 & 100.0 & \\
\hline
\end{tabular}

The sex mostly affected was seen to be males in most of the year under study. Also the age range of under 10 years and closely followed by 10-20years. However, none of the patient in our study population had clinical suspicious of malignancy.

\section{Discussion:}

The general overview of the data showed that children and infants under age range of below 10 years are the most vulnerable in the enlargement of the tonsils. Also when we compared the gender ratio of the rates of occurrence in the whole study male to female (228:164) we found it to be 1.39: 1 . These may be attributed to late in development of the adaptive immunity which is more powerful than innate immunity in combating infections. The gender distribution per year representation showed marked increase in males though no definite reason was known to be the cause. In most of this cases it appeared unilateral tonsilar enlargement; while in a few cases bilateral enlargement are seen. The unilateral enlargement seen in few cases are considered to be a sign of a potential tonsilar malignancy. ${ }^{6}$ Hence the traditional belief of otolaryngology, is to think of unilateral hypertrophy neoplasm until proven otherwise. This is why in most regions there is this belief of performing tonsillectomy as a routine. In other areas tonsillectomy are merely performed based on infective causes and in cases of obstruction symptoms such as snoring and sleep apnea. It is common practice to send tonsillectomy specimens routinely for histology examination as to exclude occult malignancy. It is suggested that among other factors missing occult malignancy or chronic granulomatous disease could lead to medico-legal issues hence the need for this suspected samples to be examined in some cases at histological unit.

However, in our study none of the patient samples were seen to be malignant. This is equally the view of similar study done at Malaysia where all pediatrics cases that had tonsillectomy were seen to have no malignancy. ${ }^{4} \mathrm{~A}$ few other studies had same view as above that all tonsillectomy offered to these age groups had no malignant involvement. ${ }^{19,20}$ This is why we are of the opinion that routine histology examination of tonsillectomy in pediatric patients of these age range is un-necessary. 
LIMITATIONS: In most if not all there is no follow up to verify other causes to the reactive responses of these group of lymph nodes of the patient. These could have indicated any primary lymphoma as a causative agent or any other secondary response from head and neck malignant lesion. The gender differentiation and any dietary attribute could not be known.

\section{Conclusion:}

This study shows that the lower age range are the most vulnerable in our study. These falls into the pediatric age hence, we recommend that tonsillectomy should not be a basis of treatment in this age group except in highly life threatening situation.

\section{Acknowledgement:}

I wish to acknowledge the effort of Engr Anthony IfechiAnaedu with sub specialist(MSc) in information Technologist(ICT) expert for helping out in the statistical analysis.

\section{References:}

[1]. Brad W. Neville,Douglas D. Damm, Carl M.Allen et al. Oral and Maxillofacial Pathology $3^{\text {rd }}$ Edition Chapter 13 Page 57172.

[2]. Harshmon. Textbook of Pathology $5^{\text {th }}$ Edition Chapter 14. Page 443-44.

[3]. Acar G.O, Yener M, Causiz H et al. Massive lymphoid presenting with obstructive Sleep apnoea Secondary to lingual and Palatine tonsils hyperplasia. Ear, Nose,Throat J.2011,Apr;90(4):E36 [4]. Irfan Mohammad, ShahidHassa,RosdanSalim. The Routine
at Hospital university sains Malaysia-Retrospective Study and its implications. Malaysian Journal of Medical sciences, Vol.14,No.2,July 2007,PP.19-21.

[5]. AlviA,Vartanian AJ. Microscopic Examination of routine tonsillectomy Specimen: Is it necessary? Otolaryngol Neck Surg.1988 oct;119(4):361-3

[6]. Benjamin P.C.Wei,StephenO'Leary,KennethOperkin The internet Journal of Otorhinolaryngology. 2007 Philadephia: J.B.Lippincott,1994

[7]. Cotran RS, Kumar V,Collins T. Pathologic Basis of disease, $6^{\text {t }}$

[8]. Hickok DF, Miller L, Harris L. Regional Hyperplastic Lymph

Unilateral Tonsil Enlargement. A challenge to the traditional thinking. vol.6,Number 1.DoI:10 5580/10ceRubin E,Farber J. Pathology $2{ }^{\text {nd }} E d n$. macrophages. An immunological study with a five-year follow up. Surgery.1997;82(5):710

[9]. Lachmann PJ, Mitchison NA. The immune response to tumors. In: Lachmann PJ, Peters DK(eds) Clinical Aspects of immunology. Oxford: Blackwell Science,1982;Ch.43.

[10]. Currie GA. Immunological aspects of human Cancer. In: LachmannPJ,Peters DK(eds) Clinical Aspects of Immunology. Oxford: Black well science, $1982 ;$ Ch.44

[11]. Maieses RL, Segal GH,IturraspeJA,BraylanRc. The cell Surface antigen and DNA contact distribution of lymph nodes with reactive hyperplasia. Modern Pathology 1995;8(5): 536-43.

[12]. Martin JM,Warnke RA. A qualitative Comparison of T-cell section immunohistochemistry. Cancer.1984;53(11):2450-5

[13]. PalutkeM,schnitzerB,MirchandaniI,et al. Increase numbers in reactive hyperplasia of lymphoid tissue. Am J. of Clinical

[14]. AisenbergAC,Wilkes BM. Lymph node T cells in Hodgkins resetting techniques. Blood.1982;59(3):522-7

[15]. BraylanRc, Rappaport H. Tissue immunologlobulins in

[16]. Heffner DK. Pathology of Tonsils and adenoids.

nodular lymphomas as compared with reactive follicular hyperplasias. Otolaryngologic Clinics of North America. 1987;20(2): 279- 286.

[17]. ErdagTK,EcevitMC,GuneriEA,DoganE,IkizAO,Sutay S. Pathologic Evaluation of routine Tonsillectomy and adenoidectomy Specimen in the pediatric Population: Is it really necessary? Int J Pediatric Otorhinolaryngol 2005 oct;69(10): 1321-5.

[18]. YounisRT,HesseSV,Anand VK. Evaluation of the utility and cost -effectiveness of obtaining histopathologic diagnosis on all routine tonsillectomy specimens. Laryngoscope.2001 Dec;111(12):2166-9

[19]. Strong EB,RubinsteinB,Senders CW. Pathologic Analysis of routine Tonsillectomy and adenoiodectomy Specimens. Otolaryngol Head Neck Syrg,2001 Nov,125(5): 473-7. 